\title{
Evidence-based TDM for antiretroviral drugs
}

\author{
Caroline Solas \\ From $16^{\text {th }}$ International Symposium on HIV and Emerging Infectious Diseases \\ Marseille, France. 24-26 March 2010
}

\section{Aim}

Evidence-based practice is essential to improving patient safety and the effectiveness of health care practices. The impact of therapeutic drug monitoring (TDM) on patients outcomes must be evaluated accordingly. Members of the 'TDM group' of the French Society of Pharmacology and Therapeutics worked together to address the role of TDM for various drugs. HIV protease inhibitors (PI) and non nucleoside reverse transcriptase inhibitors (NNRTI) have been evaluated in this context.

\section{Methods}

A systematic review of the literature was done. Published studies were analyzed and classified according to the methodology used: randomized or not, number of patients, exposition-efficacy and/or toxicity relationship, statistic method, pharmacokinetic parameters evaluated.

\section{Results}

The level of evidence for the TDM of atazanavir, amprenavir, lopinavir, indinavir, saquinavir, efavirenz and nevirapine was evaluated. Several controlled and noncontrolled studies have been performed for these drugs, reporting pharmacokinetic-pharmacodynamic correlations on treatment efficacy and for some adverse effects, such as atazanavir and bilirubin elevations or efavirenz and neurological disorders.

\section{Discussion}

The level of evidence of the interest of first generation PI and NNRTI TDM is recommended, which is in accordance with the French and European recommendations for the management of HIV-infected patients.

Laboratoire de Pharmacocinétique et de Toxicologie, Hôpital de La Timone, Marseille, France

B̈oMed Central @ 2010 Solas; licensee BioMed Central Ltd.
Published: 11 May 2010

doi:10.1186/1742-4690-7-S1-I11

Cite this article as: Solas: Evidence-based TDM for antiretroviral drugs.

Retrovirology 2010 7(Suppl 1):111.
Submit your next manuscript to BioMed Central and take full advantage of:

- Convenient online submission

- Thorough peer review

- No space constraints or color figure charges

- Immediate publication on acceptance

- Inclusion in PubMed, CAS, Scopus and Google Scholar

- Research which is freely available for redistribution

Submit your manuscript at www.biomedcentral.com/submit
C Biomed Central 